\title{
Selected Reference Books of 1994
}

\section{Eileen Mcllvaine}

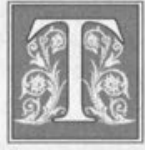

his article follows the pattern set by the semiannual series initiated by the late Constance M. Winchell more than thirty-five years ago and continued by Eugene P. Sheehy. Because the purpose of the list is to present a selection of recent scholarly and general works of interest to reference workers in university libraries, it does not pretend to be either well balanced or comprehensive. A brief roundup of new editions of standard works is provided at the end of the article. Code numbers (such as AD540 and 1CJ251) have been used to refer to titles in the Guide to Reference Books, 10th ed. (Chicago: ALA, 1986) and the Supplement ...Covering Materials from 1985-1990 (Chicago: ALA, 1992).

\section{Biography}

Deutsche Biographische Enzyklopädie (DBE).

Ed. by Walther Killy. Munich: K.G. Saur, 1995-. v.1-. (ISBN 3-598-23160-1). In progress, to be in $10 \mathrm{vols}$.

This encyclopedia attempts to provide brief, factual information about Germans who had an impact on the culture, intellectual development, or history of their period; it does not include those currently living. When complete, its estimated 56,000 entries will offer broader but briefer coverage than the other two standard German biographical sources: the 26,000 -en- try, 56-volume Allgemeine deutsche Biographie (1875-1912. AJ202), and the still in progress Neue deutsche Biographie (AJ207).

I did a brief comparison between the first volumes of the $D B E$ and the $N D B$. The first entry in both is Hans Aachen, who gets one and a half columns in the $N D B$, with ten additional sources. The new encyclopedia gives him a brief paragraph, with one additional source (indicated by a charming icon of an open book); the additional source is an art dictionary published in 1922; the NDB entry is not cited. With a few exceptions for some longer, signed entries (Bach and Bismarck), only one additional source, often the $N D B$, is provided.

Most, though not all, of the entries in the $N D B$ are in the newer work, while quite a few of the encyclopedia entries are not in the NDB. Any large library will need to add this new work for its breadth, and smaller libraries will find it a useful and convenient source.-M.C.

\section{Religion}

Bitton, Davis. Historical Dictionary of Mormonism. Historical Dictionaries of Religion, Philosophy, and Movements 2. Metuchen, N.J.: Scarecrow Press., 1994. 339p. \$39.50 (ISBN 0-8109-2779-4). LC 93-3592.

Historical Atlas of Mormonism. Ed. by S. Kent Brown, Donald Q. Cannon, and

Eileen McIlvaine is Head of Reference and Collections, Butler Library, Columbia University, New York, NY 10027. Although it appears under a byline, this list is a project of the Reference Departments of Columbia University Libraries, and notes are signed with the initials of one of the following staff members: Kathe Chipman, Katherine Keller, Avery Library; James L. Coen, Business Library; Mary Cargill, Olha della Cava, Robert H. Scott, Sarah Spurgin, and Junko Stuveras, Butler Library. 
Richard H. Jackson. New York: Simon \& Schuster, 1994. 169p. 32cm. \$37.50. (ISBN 0-13-045147-0.) LC 94-21912.

The authors and editors of both works teach at Brigham Young University (BYU) and at the University of Utah, and, from the tone of the introductions, are members of the Mormon Church. (The entry for BYU in the Historical Dictionary alludes to the "uniqueness or special aura that sets BYU apart from most other universities"-p. 44.)

Both introductions clearly establish the authors' points of views. The atlas is a portrait of success: "The 20th century brought ever increasing growth to the Mormon church . . . [and] has transformed it into a worldwide multicultural organization whose membership remains committed to the doctrines and beliefs espoused by the Prophet Joseph Smith, Jr." (Introd.). The author of the Historical Dictionary of Mormonism feels that the spectacular growth of the church, from a handful in 1830 to the eight million today, is due in part to Mormonism not being a new religion but "rather a restoration of the same church Christ established, bringing back the same doctrine and authority" (Introd.). The Mormons are successful, he feels, because they "scorn the values of the Hollywood elite and mass media ... [and] will continue to advance their religion." He adds, however, that "it would serve no useful purpose in an introductory dictionary to engage in polemic" and both works avoid the blatant partisanship of the five-volume Encyclopedia of Mormonism (New York: Macmillan, 1992), whose entries tend to be extensive quotations from and justifications for official Mormon doctrine.

The atlas is divided into brief chapters with maps on one page and text accompanied by short bibliographies on the facing page. The maps concentrate on the early history and current worldwide growth of the church but lack any serious sociological or economic analysis of its members. The dictionary is arranged al- phabetically, with short (usually a paragraph) entries for people, events, and beliefs. It has a lengthy bibliography, citing mainly Mormon imprints, making it a very useful guide to primary sources.

Though by no means objective overviews either of the outstanding American success story nor of the reasons for the hatred and violence the Mormons have faced, these are useful sources illustrating the strength of the religion.-M.C.

\section{English and American Literature}

Oxford Companion to Twentieth-Century

Poetry in English. Ed. by Ian Hamilton.

Oxford: Oxford Univ. Pr., 1993. 602p.

\$38.25. (ISBN 0-19-866147-9.) LC 931436.

This book is intended to be a reference work as well as a history, a map for exploring poetry in English since 1900. It includes not only Great Britain and the United States but also Australia, Canada, and other English-speaking countries, and covers about " 1,500 poets, including 550 British, an equal number of American, 120 Australian, 110 Canadian, 60 African and 40 Asian poets. Among them are 200 women and 100 Blacks" (p. xi). Another 100 or so entries cover subjects, e.g., schools, movements, notable magazines. The major emphasis of this guide is on individual poets and a typical entry for a poet includes a brief biography, critical appraisal, list of major works, and a bibliography. Entries are signed with the initials of the contributor.

This work is better than many of the encyclopedias of literature which are often mere repackaging of previous works without any clear editorial concepts behind them. It is suitable for a wide readership, from high school students to graduate students who want a concise, wellwritten essay for a quick review. General poetry readers will enjoy it too.-J.S.

Pitcher, Edward W. R. Fiction in American Magazines before 1800: An Annotated Catalogue. Schenectady, N.Y.: Union 
College Pr., 1993. 321p. \$42.50. (ISBN 0-91275-627-6.) LC 93-060539.

It is always so satisfying when someone publishes a reference book that is useful and fills a need. Fiction in American Magazines before 1800 provides new access to early American periodical fiction while showing the degree to which American periodicals borrowed from English and French literature.

The author has searched all the titles in the UMI American Periodicals Series (and some of the titles in APS II; see AE26) as well as selected titles in the Readex Microprint series Early American Newspapers. Works of fiction are listed alphabetically by title, and entries include the citation, source (e.g., whether a reprinting of a British story or a translation of a French work), and further printings. A separate author, signature, and special subject index lists entries for authors' names and pseudonyms, with a few special interest lists for fiction relating to Native Americans, slaves, and, by far the largest, stories from or treating Asia. Another section provides a chronological listing of fiction published within each magazine, and the final section provides a checklist of sources. Highly recommended for all libraries supporting study of American literature.-S.S.

\section{Slocum, Robert B. New England in Fiction} 1787-1990: An Annotated Bibliography. West Cornwall, Conn.: Locust Hill Pr., 1994. 2 vols. 980 p. $\$ 100$. (ISBN 0933951-54.) LC 93-47349.

New England in Fiction is an annotated bibliography of 4,975 works of fiction, mostly novels and short stories, published in the United States between 1787 and 1990. The works have New England (i.e., Maine, New Hampshire, Vermont, Massachusetts, Rhode Island, and Connecticut) as their setting. Works of drama, poetry, and children's fiction are excluded. The annotations, mainly plot summaries, were either composed by the compiler, or excerpted from book reviews.
This monumental compendium makes a significant contribution to the literary history of the U.S., but the compiler had a more specific purpose in mind: to show how writers of diverse eras and backgrounds, including non-New Englanders, portrayed the "Yankee" character and locale in their fictional writings. Thus, while the alphabetical author arrangement of the entries, the title index, and the chronological listing of works published between 1787 and 1865 make this bibliography a superb look-up tool, it is the subject and place indexes through which new perspectives on the changing history and character of the region and its inhabitants can be traced.-O.dC.

\section{European Literature}

Dictionary of Polish Literature. Ed. by B. J. Czerwinski. Westport, Conn.: Greenwood Pr., 1994. 488p. \$85. (ISBN 0-3132622-5.) LC 93-49540.

With the publication of this volume, the amount of reference information in English on a major European national literature has taken a quantum leap. Compiled by Edward Czerwinski, Halina Gerber, and Jan Wojnowski, this work is based closely on-and in many places represents a near translation or summary ofan earlier, much larger work in Polish, Literatura Polska: Przewodnik Encyklopedyczny (Warszawa: PWN, 1984-1985. 2 vols. Suppl. 1987). However, pains have been taken to bring the treatment up to date, including significant new coverage of emigré and underground literature not treated in the source text.

The result is a volume of approximately 150 articles, mostly devoted to individual authors from the Middle Ages to the present, but also including articles on the major periods of Polish literary history, on Poland's universities and their place in literature and literary criticism, and on a few key journals and anonymous works. Unfortunately, the overviews of individual periods are filed alphabetically among the other entries so 
that a user must know, for example, that coverage of the period from the 1860 s to the 1890 s is to be found under the heading "Positivism." Even more problematic is the apparent assumption that nonPolish readers will know the Polish names for the period $1890-1918$ or for the unofficial, uncensored literature of the 1970 s and 1980s (they are filed under "Młoda Polska" and "Drugi Obieg" respectively with no cross references). Each entry concludes with a very brief bibliographic listing, including the most important edition or editions of an author's work, one or two key studies, and any significant translations into English. The work concludes with a two-page bibliography of surveys in Polish and English and an index of proper names.

In any case, this work represents a significant new source of information about Poland's rich literary heritage for nonPolish readers, and while advanced researchers will want to consult the Polishlanguage source for fuller coverage, they, too, will find some important supplementary material here. It is thus well suited for both public and academic libraries with significant coverage of world literature in general, and essential for all with serious coverage of the Slavic and East European fields.-R.H.S.

\section{Kunoff, Hugo. Portuguese Literature from} Its Origins to 1990: A Bibliography Based on the Collections of Indiana University. Metuchen, N.J.: Scarecrow Pr., 1994. 497p. \$49.50. (ISBN 0-8108-2844-8.) LC 93-49699.

Indiana University Library's collection of Portuguese literature is one of the richest in the country, especially in works by and about the major Portuguese literary figures. This bibliography is based on that library's holdings, including the holdings of its rare book library. It extends beyond commonly held materials to ephemeral and related works, such as single plays, biographies of actors, sermons, accounts of voyages of discovery, and the works of early historians. It covers Portuguese literature from its beginnings to 1990 , with some post-1990 titles also added.

The main body of the work is devoted to individual authors, listed alphabetically within several time periods, followed by entries for works by and about them. But there are several other sections, including a chapter devoted to bibliographies, a section on literary history and criticism, one on collections of literary works, and a list of the major periodicals in the field.

Though not a definitive bibliography, it is thorough, comprehensive, and well organized, and has the added virtue of assuring the scholar that a listed item is at least available at the University of Indiana Libraries.-O.dC.

Reader's Encyclopedia of Eastern European Literature. Ed. by Robert B. Pynsent with the assistance of S. I. Kanikova. New York: HarperCollins, 1993. 605p. \$50. (ISBN 0-06-270007-3.) LC 93-2953. It would be an understatement to say that the rich and diverse literatures of Eastern Europe are not well known in this country, and so this one-volume work should be a welcome addition to the reference collections of all academic libraries and public libraries with serious coverage of world literature. Compiled by a team of twenty-four specialists from the University of London and various other institutions, it surveys the writers and, to a lesser extent, history and key anonymous or collective works of the literatures of those European peoples who have been subject, at some point, to the German, Austro-Hungarian, Russian, or Ottoman empires, excluding writers or works in the "imperial" languages (German, Russian, and Turkish) as well as the works of those writers, such as Joseph Conrad or Guillaume Apollinaire, who wrote primarily in some other foreign language. The group so defined comprises Albanian, Bulgarian, Byelorussian, Croa- 
tian, Czech, Estonian, Finnish, Greek (Byzantine and Modern), Hungarian, Latvian, Lithuanian, Macedonian, Polish, Romanian, Serbian, Slovak, Slovene, Sorbian, Ukrainian, and Yiddish, along with Armenian and Georgian. The emphasis of the work, moreover, is almost exclusively on belles lettres.

The first and largest section of the work, following a brief historical introduction, consists of entries for some 850 East European writers, providing a brief outline of the lives and work of each, as well as some indication of their place in the broader context of their national literary tradition. Listings of up to three key translations or critical works follow many of the articles. Individual contributors were given relative freedom in deciding whom to include and how much or little to write (although few if any of the entries are more than a page and a half in length). As a result, the extent of coverage is not always proportional to the relative sizes of the various national literatures. In some cases, this means an unexpected but welcome richness of treatment for small and littleknown (in this country at least) national literatures, such as Albanian and Georgian, but in other cases, coverage is smaller than one might hope-just twenty-one entries for authors in Ukrainian (the largest of the language groups represented here) as compared with nine for Sorbian (the smallest group of speakers). Most major authors are included. Although inevitably, as in any work of this kind, there are omissions of writers a reader would have expected to find-this reviewer wonders, for example, about the absence of such important figures as Polish authors Kazimierz Brandys or Bruno Szulc, or the prolific and influential medieval Bulgarian writer Gregory Tsamblak.

The second section is devoted to anonymous and collective works, opening with a useful survey of Bible translations into all of the languages of the re- gions. The rest of this section, however, reflects most sharply the freedom of choice given to individual contributors. Many important works are included here, but there is not the kind of comprehensive coverage one might expect to find in an encyclopedic work. Thus, for example, while there are brief surveys of Finnish, Georgian, and Greek oral poetry and entries for two Greek and one Armenian work under the related heading of "The Epic," there is no treatment of the very well-known South Slavic oral epic tradition. Likewise, under the promising heading of "The Chronicle," there is only one entry, for Georgia.

The last section of the work consists of brief survey histories of each of the national literatures, along with brief listings of key bibliography. Access to the work as a whole is facilitated by three indexes, one containing lists of the authors covered, grouped according to language; another listing the anonymous or collective works surveyed (essentially a table of contents for that section); and a third, general index of names and subjects, providing a reasonably detailed guide to the coverage of themes, movements, and other subjects in the individual entries.

As suggested here, this work is not a perfect one, but it is the only source of its kind currently available, and hence ought to be given serious consideration as an addition to any world literature reference collection. At the same time, however, readers will want to continue to supplement its coverage with the information contained in broader surveys such as the Columbia Dictionary of Modern European Literature (BD52).--R.H.S.

\section{Performing Arts}

Brewer's Theatre: A Phrase and Fable Dictionary. London: Cassell; New York: HarperCollins, 1994. 513p. \$35. (ISBN 0-06-2700-43-X.) LC 94-016436. Inspired by the well-known Dictionary of Phrase and Fable (BD89), this work "aims 
to cover all aspects of theatrical life, language, and legend ... [ [and to provide] a treasury of fascinating and out-of-theway information not usually included in conventional reference books" (Pref.). It has a definite British slant, but considering Britain's theatrical preeminence, this is not a major drawback. But surely the term "green room" is not limited to the Drury Lane Theatre and "several other theatres" (p. 202). It is arranged alphabetically, with brief paragraphs discussing actors, playwrights, plays, and theatrical expressions. Much of the information can be found in other, similar reference works such as the various Oxford companions and the Cambridge guide, but these don't have such priceless tidbits as Kenneth Tynan's pan of the Flower Drum Song as "the world of woozy song."-M.C.

\section{New York Public Library Performing Arts}

Desk Reference. New York: Macmillan, 1994. 424p. \$35. (ISBN 0-671-79912.) LC 94-22673.

This dictionary/directory/bibliography divides performing arts into three sections - theater, music, and dance-and provides brief overviews of some of the main events. "The evolution of Western theater" takes four pages, "Introduction to opera" gets eleven pages, and the life and work of William Shakespeare gets three pages. There are brief biographies of some major players in these fields, lists of some major awards (all American), and brief bibliographies. Brevity has its drawbacks, and subtlety is not one of this work's strengths. Some of the entries sound as if they came from high school term papers: "It is an amazing fact that Beethoven wrote most of his work after he had gone deaf in 1802" (p. 157); and "Wagner also introduced the idea of Leitmotif to music" (p. 173). The facts selected are not always of primary importance. We are told that Carla Fracci is the great-grandniece of Giuseppi Verdi, but not of her long association with the
American Ballet Theatre or of her partnership with Eric Bruhn.

All the information can be found in other, more complete reference sources and it is hard to imagine why a librarian who has available, for example, the New Grove's Dictionary of Music and Musicians (BH129) would ever use the music portion. The cachet of the New York Public Library may be a selling point but this is not a necessary addition.-M.C.

\section{Art}

Bibliography of Gay and Lesbian Art. Ed. by James M. Saslow. New York: CAA Gay and Lesbian Caucus, 1994. 112p. $\$ 18$.

The College Art Association (CAA) is breaking ground with its Bibliography of Gay and Lesbian Art, begun in 1992 as a collaborative effort. It consists of 11,000 entries (plus some 100 reviews); most, but not all, entries have brief annotations, current through 1992 and covering Englishlanguage publications (books, journals, and museum publications). Arrangement is by twelve broad topics: surveys and general works; [seven period and medium divisions]; AIDS and the arts; theory and criticism, methodology, historiography; non-Western art; bibliographies and research resources [including unpublished materials]. Monographs on individual artists are selectively cited. The index is chiefly to artists and authors, with a few organizations and subjects.

Related titles include Gay and Lesbian Studies in Art History, edited by Whitney Davis (New York: Haworth Pr., 1994. 308p. \$49.95; first published in 1994 as vol. 27, nos. 1-2 of Journal of Homosexuality), which features twelve essays, footnotes, and a name index; and Cassandra L. Langer's Feminist Art Criticism: An Annotated Bibliography (New York: G.K. Hall, 1993. 291p. \$50), the primary useful source in conjunction with the CAA bibliography. Within several index entries for lesbians, gay men, and related topics are some fifty references.-K.C. 
Byars, Mel. The Design Encyclopedia. New York: John Wiley, 1994. 612p. $\$ 60$. (ISBN 0-471-02455-4.) LC 94-9079.

The intent of this work is "to provide accurate and detailed information on people, firms, and materials, directly associated with the production of the decorative and applied arts in the past 125 years. Most of the entries are for designers of furniture, textiles, glass, metalware, wallpaper, and interiors as well as ceramicists, industrial designers, and interior architects. There are no fine artists, photographers, architects, and graphic, fashion, and vehicle designers, except those active, if only peripherally, in the decorative and applied arts" (Introd.). The geographic scope of this work covers Eastern and Western Europe, Japan, Australia, and North and South America. Its stated aim is to be as comprehensive as possible.

The approximately 4,800 entries, threequarters of which are biographical, are arranged alphabetically and are divided into the following categories: general description and birthplace; awards; and a chronological bibliography. The Encyclopedia includes, at the end of the volume, chronological listings of international and specialized exhibitions, fairs, and the Biennali di Monza and Triennali di Milano.

Notable biographical omissions in this volume include Ralph Lauren, Mark Hampton, Clodagh, and Gianni Versace. When compared with Contemporary Designers (IBF14) and Contemporary Architects (IBE132), the coverage is broader, but the Encyclopedia lacks the signed biographical essays, the interspersed illustrations, and the comprehensive bibliographical information with items both by and about the designer. However, the Encyclopedia's entries for manufacturer, firm, movement, design store, and material provide useful information which is often difficult to find.

Arranged in two-column format, the entries are in bold and daggers are used to mark the different categories of information. This arrangement works well. Four sixteen-page sections of black-andwhite photos are included in the volume. The Encyclopedia lacks an index.

This work brings together the diverse world of design in a single alphabetic sequence. Despite the omissions listed above, the Design Encyclopedia will fill in some gaps in academic and public collections that do not have strong biographical reference sources, particularly in the decorative and industrial arts.-K.K.

\section{Women's Studies}

Sherr, Lynn, and Jurate Kazickas. Susan

B. Anthony Slept Here: A Guide to American Women's Landmarks. New York: Times Books, 1994. 580p. \$18. (ISBN 0-8129-2223-9.) LC 93-28701.

This is a fun and informative guide, filled with much local color. Some 2,000 landmarks are listed, from Carrie Chapman Catt's birthplace in Ripon, Wisconsin, to Niagara Falls, where in 1901 Annie Edson Taylor became the first person to go over the Falls in a barrel-and survive. The guide is arranged by state and then city, with many black-and-white photographs, an index, and a bibliography. Because the authors have sought to list landmarks from throughout the United States, criteria for inclusion seem to vary by state. There are more pages devoted to Arizona than to Illinois, for instance, and the Blue Guide to New York (New York, 1983) lists far more women's landmarks than are found in the thirteen pages allotted here. Having said this, it is still an amusing and useful reference work, recommended for libraries of all sizes.-S.S.

\section{African-American Studies}

Black Women in America: An Historical Encyclopedia. Ed. by Darlene Clark Hine. Brooklyn: Carlson Publishing, 1993. 2 vols. (1,530p.) \$195. (ISBN 0-92602962-9.) LC 92-39947.

This two-volume, thoroughly researched, well-organized, illustrated encyclopedia 
is a welcome addition to the literature on the role played by Black women in American history. The encyclopedia consists of 641 biographies of individual Black women, and 163 articles which deal with general topics and organizations in which Black women played a central part. Of particular importance is the fact that many of the persons and topics included here have not appeared previously in standard sources.

The articles are written by specialists, enhanced by well-chosen photographs, and always conclude with a bibliography of sources for further information. This standard format makes the work easy to use, while a back-of-the-book index, a list of topical entries, and another of biographical entries arranged by profession enhance access. A Chronology of Black women's history (1619-1992), a bibliography of basic resources in the field, including a list of major research collections of primary materials, and informative notes on the editors and contributors make this one of the best all-in-one reference tools on this subject available to date.

As thorough as this work is, it nevertheless admits to slighting contemporary women. Fortunately, there are other reference sources which pick up the slackamong them African American Biographies: Profiles of 558 Current Men and Women and its 1994 supplement, African American Biographies 2: Profiles of 332 Current Men and Women, both compiled by Walter L. Hawkins [Jefferson, N.C.: McFarland, 1992-1994. 2 vols. (490p., 367p.)]. About a third of the entries are for women; to be included one must qualify as a "role model." The main volume includes biographical sketches for women who were alive in 1992 or had died in or before 1968 . The supplement extends coverage to those who were living in 1994 or had died before 1976. Photographs accompany most of the entries.-O.dC.

African-American Mosaic: A Library of Congress Resource Guide for the Study of
Black History and Culture. Ed. by Debra Newman Ham. Washington, D.C.: Library of Congress, [1994]. 300p. \$24. (ISBN 0-8444-0800.) LC 9321605. (Superintendent of Documents no.: LC 1.6/4:AF 8)

The African-American Mosaic is simultaneously a chronological survey, a bibliographic essay, and a documentary history. Nine chapters trace the experience of American Blacks from slavery through the Civil Rights era. Incorporated into the narrative are the Library of Congress' (LC) relevant book, manuscript, and visual holdings. The text is printed on highquality paper and richly illustrated with superb color and black-and-white reproductions of photographs, posters, flyers, drawings, and etchings from the library's collections.

The stated purpose of this guide, however, is not so much to be an illustrated chronological history, but an aid to researchers by providing a survey of LC holdings in Black history and culture. The compilers of the guide fulfill this goal by providing a name, title, and limited subject index, and by adding LC location symbols to the bibliographic references in the narrative. To the serious researcher and reference librarian the traditional annotated bibliography and collection level archival guide, provided they are thorough and well organized, are preferable. Nevertheless, it is a beautiful and informative book.-O.dC.

Crayton, Tabatha. The African-American Address Book. New York: Berkley Pub., 1995. 288p. \$11. (ISBN 0-399-52148-8.) LC 94-30205.

This is a useful little book, provided one accepts its limitations. It is useful because it brings together in one compact volume the addresses and phone numbers of some 3,500 individuals and equally as many agencies and organizations in the areas of media, arts, entertainment, writing, publishing, sports, religion, education, business, and politi- 
cal and cultural life. Within each area, however, the coverage is uneven. While such sections as "Newspapers" or "Colleges and Universities" are quite comprehensive, other sections - such as "Educators" with 103 entries, or "Historians" with four entries - clearly fall short of covering the field. It is, however, a good place to start. Unfortunately, there is no index, so looking up a known name is difficult.

If your library needs more thorough coverage of African-American institutions and organizations, and more extensive information than simply name, address, telephone number, and a oneword identification here and there, the Black Americans Information Directory 1994/ 95, edited by Wendy S. Van de Sande (3d ed. Detroit: Gale, 1993. 556p.; 1CC205) with its 5,300 organizations, agencies, associations, institutions, programs, publications, libraries, museums, etc., is a much better reference tool than the African-American Address Book.-O.dC.

\section{Business}

Haridbook of Equity Derivatives. Ed. by Jack Clark Francis, William W. Toy, and J. Gregg Whittaker. Chicago: Irwin Professional Pub., 1995. 685p. \$85. (ISBN 1-5562-3594-1.) LC 94-21173.

The editors state in the preface that their goal is "to allow nonspecialists to gain an understanding of the basic behavior of equity derivative structures." They are careful to indicate that in this work they are concerned exclusively with equity derivative instruments, and that the book's viewpoint is geared toward the United States investor.

In twenty-seven chapters the assembled experts, the majority of whom are seasoned practitioners, present detailed description and analysis of every aspect of equity derivatives. The chapters are grouped into six parts comprising an introduction to the basics of equity derivatives, the domestic and international markets for these instruments, the types of derivatives that corporations issue based on their own stock, synthetic structures, the particular regulatory features (including tax, legal, and accounting) of equity derivatives, and, finally, essays on the current state of equity derivatives and their markets. Many of the chapters are written in a "how-to" style, laying out theory and practice, and frequently amplifying these with case study examples.

There is no overall bibliography, but several of the chapters append their own; there is a general index. A very useful addition to most academic and some public business libraries.-J.L.C.

\section{European History}

Atlas de la France de l'an mil: état de nos conaissances. Sous La Direction de Michel Parisse. Paris: Picard, 1994. 129p. 31x31cm. 350F. (ISBN 2-708404057-1.) LC 94-213533.

The Atlas divides the France of Robert II the Pious in the year 1000 into twelve areas, such as Aquitaine and Gascony, Central France, Flanders, Picardy. For each region, three maps are presented with an explanatory text and a bibliography. The first map shows the seats of archbishoprics, bishoprics, monasteries, and other religious establishments within diocese borders. The second is a map of fortifications: castles, towers, etc. The sites mentioned in contemporary documents and those based on archeological research or later documents are marked differently. The third map indicates sites of economic activities: cities, markets, tolls, bridges, ports, fishing, manufacturing and mining, mints. Rivers and coastlines, both historical and current, are indicated.

Each map is accompanied by a list of place names with brief explanations of documentary sources. Concluding the volume are a general index of names from Latin to French and an index to maps by French place names.

This atlas is suitable for university libraries which have comprehensive collections in European history and special li- 
braries which have strong European medieval collections.- J.S.

\section{Sanford, George, and Adriana Gozdecka-} Sanford. Historical Dictionary of Poland. European Historical Dictionaries, 3. Metuchen, N.J.: Scarecrow Pr., 1994. 339p. \$49.94. (ISBN 0-8108-2818-9.) LC 93-43939.

This third volume in a promising series by Scarecrow Press is devoted to the history of Poland, a topic not particularly well covered in English-language reference sources to date. The heart of the work is a dictionary of approximately 420 entries, providing brief, concrete information about key political and cultural figures, historical events, political parties, major cities and regions, government institutions, religious groups, and cultural organizations. Included here as well are slightly longer discussions of art, education, literature, and other cultural topics, and surveys of relations with individual neighboring countries. Preceding the dictionary itself is a variety of useful front matter, including a chronological table, a list of rulers, a list of important acronyms, a (too tiny) map of the country, and a twenty-four-page overview of key features and developments in the country's geography, economy, and history. At the book's end is an extensive (100 pages), useful bibliography of the key Englishlanguage literature on Polish affairs. There is no index, however, and few cross-references.

While the work encompasses the whole of the country's history from the ninth century up through 1994, it is particularly strong in its coverage of the twentieth century. Indeed, it is strikingly up-to-date with its useful characterizations of many contemporary politicians and parties. Coverage of the medieval and early modern periods are less comprehensive, although that is probably inevitable in a volume of this size. A more serious shortcoming, however, is the decided de-emphasis of the former Polish-
Lithuanian state's eastern lands, which included much of present-day Lithuania, Belarus, and Ukraine. While these lands are certainly no longer part of postwar Poland, they were a crucial component of its history and culture for more than 500 years, and a fuller treatment of this area certainly seems to be needed. (For example, the guide contains no references to Wilno (Vilnius) or Lwow (Lviv), two urban centers of prime significance to Polish history and culture, even though both now lie outside the borders of the Polish state.)

These qualifications notwithstanding, this book is a well-written and much needed addition to the field. Students and researchers will find it a handy personal reference, and libraries with serious coverage of European history should certainly add it to their reference collections.-R.H.S.

Times Atlas of European History. Contributors: Mark Almond et al.; maps prepared by Bartholomew, Edinburgh. London: Times Books; New York: HarperCollins, 1994. 206p. \$40. (ISBN 0-05-270101-0.) LC 94-213533.

The Times Atlas covers the historical period from 900 B.C. (Mesopotamian cities) to 1993 (the fall of communism), presenting European political systems at fortysix key dates. The emphasis is clearly and intentionally on political systems from the rise of Near Eastern city states to the demise of the Eastern Bloc under the Russian hegemony. Most sections consist of two facing pages divided between maps and text to explain the historical development presented by the maps. Major events such as Revolutionary Europe, the Congress of Vienna, and the Unification of Germany are given twice the space.

The Atlas is very narrowly focused on the territorial states in Europe. Readers should not expect to find a map of the British Empire or the discovery of the New World, but rather should expect a map on the growth of Jagiello power 
(1440-1526) or the development of the Swiss Confederation (1291-1526). The introduction proposes this approach to European history as a framework and a starting point for other kinds of history which might deal with mentalities, ideas, institutions, and movements.

The same size basic map of Europe is used throughout, and this makes it easier to compare, for example, the Habsburg possessions with the Napoleonic conquest. The concise text captures the zest of political history. The geographical index is detailed to direct the reader to the place name at a specific historical period. The volume ends with a bibliography of historical and thematic atlases, gazetteers, and books on European political history.

This Atlas should be used in conjunction with an atlas of world history. Scholars would not be doing justice to the European political systems if we limit our scope of study to Europe proper and ignore their lasting impact on the rest of the world. As the work stands, it seems an advocate for the virtues of nation states in the face of the emerging European union.-J.S.

\section{New Editions and Supplements}

The third edition of the Bibliography of Canadian Bibliographies, edited and compiled by Ernie Ingles (Toronto: Univ. of Toronto Pr., 1994. 1,178p. \$150; 2d ed. 1972. AA47), has grown to 7,375 entries covering bibliographies from 1789 to mid-1993 and arranged by broad subjects, e.g., History and Genealogy. Fully 553 of the 1,178 pages are indexes: Authors, Titles, Subjects in English, Subjects in French, Short Entry Section, Serial Titles Searched.

The British Library has continued the bibliographies of its holdings of early printed books: Catalogue of Books Printed in the German-Speaking Countries and of German Books Printed in Other Countries from 1601 to 1700 Now in the British Library, compiled by David Paisey (London, 1994. 5 vols.) which is a sequel to Short-Title
Catalogue of Books . . . 1455 to 1600 (1961. AA768) and Supplement (1990. 1AA118); and the Short-Title Catalogue of Eighteenth Century Spanish Books in the British Library, compiled by Harold Whitehead (London, 1994. 3 vols.) which continues the Short Title Catalogue of Books Printed in Spain and Spanish Books Printed Elsewhere in Europe before 1601 Now in the British Library (2d ed. 1989. 1AA187).

Through the 1985 supplement and the volume for Missing Persons, 1,518 women were treated in the Dictionary of National Biography (AJ217, 1AJ66) and 34,533 men, for a ratio of 23 to 1 . This is one of the facts presented by Gillian Fenwick in her index, Women and the "Dictionary of $\mathrm{Na}$ tional Biography": A Guide to DNB volumes 1885-1985 and "Missing Persons" (Adlershot, Hants., England: Scholar Pr.; Brookfield, Vt.: Ashgate, 1994. 181p. \$59.95). "The book begins with a general overview of the DNB from 1880 s to the present day with particular reference to the role of women both as subjects and contributors." (Pref.). Following the essay is a list of the women who have biographical sketches, a list of women contributors, a list of male contributors who have written about women, and a table of occupations of women subjects.

The Supplement to American Women Writers, edited by Carol Hurd Green and Mary Grimsley Mason (Westport, Conn.: Greenwood, 1994. 522p. \$95; for earlier title see BD362) offers updates on many women covered in the earlier set, e.g., Alice Walker, as well as new articles on writers who have become prominent since the 1970s, e.g., Barbara Kingsolver.

A companion title is Italian Women Writers: A Bio-Bibliographical Sourcebook, edited by Rinaldina Russell (Westport, Conn.: Greenwood Pr., 1994. 476p. $\$ 89.50$ ), which describes the " 51 most significant Italian women writers of the 14 th century to the present day" (Pref.). These women have written in Italian or in Latin. Each sketch includes a biographical outline, a critical discussion of the author's 
writing including current themes and her place in literature, a bibliography of primary works and works translated into English, and a selective bibliography of criticism. The contributors are mostly from academic institutions.

The New Oxford Companion to Literature in French, edited by Peter France (New York: Oxford Univ. Pr.; Oxford: Clarendon Pr., 1995. 865p. \$49.95) is totally revised from the earlier edition, Oxford Companion to French Literature (1959. BD999). The change in title is indicative of the "shift in emphasis from French literature to literature in French." (Introd.). Articles are signed with initials and often include short bibliographies. The appendix offers a chronology in parallel columns for monarch or regime, cultural history, and authors. A section of maps is included.

The Fundamental'naia Biblioteka Obshchestvennykh Nauk has produced a number of bibliographies on history and languages (see BC2-BC3, DC520). In the late 1950s the librarians compiled a bibliography of literary theory and criticism written in the Soviet Union, in Russian, and published between 1917 and 1925: Sovetskoe literaturovedenie $i$ kritika 1917-1925: bibliograficheskii ukazatel. The compilation was never published because of disagreements with the publisher, the Akademiia NaukSSSR, which demanded that certain entries be dropped. (A shorter listing did appear in Sovetskoe literaturovedenie i kritika: Russkaia sovetskaia literatura . . . knigi $i$ stati, 1917-1962g in 1966; see BD1326). Norman Ross has now published the complete bibliography, with editorial assistance from INION (New York: Norman Ross, 1994. 3 vols. $\$ 300$ ). Consisting of 8,100 entries arranged topically, the bibliography emphasizes Russian literature most strongly but the non-Russian literatures in the Soviet Union and world literature are also covered. Volume two has specific authors.

The second edition of Women Artists: An Historical, Contemporary, and Feminist Bibliography (Metuchin, N.J.: Scarecrow
Pr., 1994. 454p. \$59.50; 1st ed., 1978. BE12) compiled by Sherry Piland, adds information on an additional twenty-nine artists but excludes women architects. It appears to be current only through 1989 and lacks an index. Coverage is still in two sections: general works (books, periodicals, catalogs) and individual artists (by century, beginning with the 15 th century).-K.C.

Robert T. Packard revised the Encyclopedia of American Architecture (New York: McGraw-Hill, 1994. 724p. \$89; 1st ed., 1980, by William Dudley Hunt Jr., BH270). It now features color photographs and expanded sections for computer use in the profession, energy conservation, accessible design, landscape architecture, and changes in design thinking, as well as new biographies of several leading individuals and firms.-K.C.

The National Register of Historic Places, 1966 to 1994: Cumulative List through January 1, 1994 (Washington, D.C.: National Park Service, Preservation Pr., National Trust for Historic Preservation, National Conference of State Historic Preservation Officers, 1994. 923p.) has grown substantially over the 1989 compilation (1BE128). Described as a collaborative venture with the compiler, African American Historic Places: National Register of Historic Places, edited by Beth L. Savage (Washington, D.C.: Preservation Pr., 1994. 623p. \$24.95) includes eight essays, brief histories of the properties, and indexes by city, occupation, names of individuals and organizations, subject, and National Register listing.-K.C.

At long last we have received the third edition of the American Historical Association's Guide to Historical Literature (New York: Oxford Univ. Pr., 1995. 2 vols. $(2,027$ p.) \$150). The second edition (DA1) is over thirty-five years old and terribly dated. The new edition has about 27,000 entries in a classified arrangement which is outlined at the beginning of each section. Also new is the discussion beginning each section which summarizes the issues 
and developments in the subject and the greater emphasis on social and cultural history, history of women, history of Native Americans. The entries are heavily English language and the whole thrust of the compilation is toward the beginning researcher or the researcher moving into a related field. The proof will come in using it, of course, but on first appearance reference librarians and researchers should be very pleased.

Joyce Horn has compiled another supplement to the previous listings of theses completed in history begun by Phyllis M. Jacobs (for earlier lists see DA25): History Theses 1981-1990: Historical Research for Higher Degrees in the Universities of the United Kingdom (London: Univ. of London, Institute of Historical Research, 1994. 319p.) based on the annual lists put out by the Institute of Historical Research at the University of London (DC286). Some 5,000 entries are classified according to period, topic, and country. Some of the titles are omissions from the previous compilations. Detailed subject index provided.

Two reference sources reflect the breakup of the Soviet Union: The Cambridge Encyclopedia of Russia and the Soviet Union (DC565) has been rewritten with particular attention to the last ten years of Communist rule. Now called the Cambridge Encyclopedia of Russia and the Former
Soviet Union, edited by Archie Brown, Michael Kaser, and Gerald S. Smith (2d ed. Cambridge: Cambridge Univ. Pr., 1994. 604p. \$50) it offers good coverage through 1991 with some additional information for 1992-1993. Heavily illustrated, many of the maps and photographs are new to this edition.

Helen F. Sullivan and Robert H. Burger are continuing the bibliographies that Stephan Horak compiled (DC23-24, 1DC13). Thus far only the volume for Russia and the former Soviet Union has appeared: Russia and the Former Soviet Union: A Bibliographic Guide to English Language Publications, 1986-1991 (Englewood, Colo.: Libraries Unlimited, 1994. 380p. \$67.50). Sullivan used ABSEES and Books in Print to pull together 1,421 titles with descriptive annotations. The volume for Eastern Europe is to appear this summer, compiled by Burger.

The Annual Egyptological Bibliography 1988-1991, compiled by L. M. J. Zonhoven with the collaboration of W. Hovestreydt (Leiden, The Netherlands: Brill, 1994. 289p. DD115), addresses the gap that has been widening in the publication schedule of the annual bibliography. This first part treats 1988-1991 publications, which are classified in the $A E B$ as books and which have been received for review. The 1992 annual is promised for 1995.

\section{College \& Research Libraries' Changes}

$C \& R L$ is now being published by the Association of College and Research Libraries (ACRL) under the direction of Mary Ellen K. Davis, Hugh Thompson, and Pam Spiegel, with editorial assistance from Darlena Davis. In addition to changing publishers, the editor and the editor-designate have made a number of stylistic changes. ACRL members may now expect copies of the journal to arrive during the third week of the month. 